\title{
Pengembangan Komik Pembelajaran pada Materi Bumi dan Alam Semesta untuk Siswa Sekolah Dasar Kelas VI di SDN Utama 2 Tarakan dan SDN 17 Tarakan
}

\author{
Roby Zulkarnain Noer ${ }^{1}$, Fadhlan Muchlas Abrori ${ }^{2}$ \\ ${ }^{1}$ Program Studi Pendidikan Guru SD, Universitas Borneo Tarakan \\ ${ }^{2}$ Program Studi Pendidikan Biologi, Universitas Borneo Tarakan \\ robyznoer@gmail.com
}

\begin{abstract}
Abstrak
Pemanfaatan media pembelajaran di dalam kelas selama proses pembelajaran pada kebanyakan sekolah di Indonesia umumnya kurang inovatif dan cenderung monoton. Monotonnya pengunaan media dalam proses pembelajaran menyebabkan siswa tidak mampu mengikuti pelajaran dengan maksimal sehingga pembelajaran menjadi tidak efektif dan efisien. Salah satu media pembelajaran yang efektif digunakan dalam kelas untuk membangkitkan motivasi dan minat siswa adalah media grafis terutama media komik pembelajaran. Tujuan dalam penelitian ini adalah untuk mengetahui kualitas komik pembelajaran yang dikembangkan. Penelitian ini merupakan jenis penelitian pengembangan (research and development). Model pengambangan dalam penelitian dan pengembangan ini menggunakan modifikasi pengembangan perangkat Four- $D$ Model. Berdasarkan hasil dan pembahasan di atas maka dapat disimpulkan: Kualitas komik pembelajaran ditinjau dari penilaian validasi dari ahli materi didapatkan hasil komik pembelajaran memiliki kriteria valid dengan presentase 90,3\%. Penilaian validasi dari ahli media didapatkan hasil validasi komik pembelajaran memiliki kriteria valid dengan presentase $87,8 \%$. Penilaian validasi ahli bahasa pada komik pembelajaran memiliki kriteria valid dengan presentase $96 \%$. Hasil uji coba lapang berdasarkan penilaian guru dan dan siswa didapatkan presentase pada guru sebesar $86 \%$ dan pada siswa sebesar $86.5 \%$ (valid).
\end{abstract}

Kata Kunci : Komik, Pengembangan, Bumi, Alam Semesta

\begin{abstract}
Generally, using of instructional media in the classroom during learning process in most schools in Indonesia is less innovative and monotonous. That problems it caused students can not followed the lesson maximally, therefore learning process becomes uneffective and unefficient. One of the effective learning media can be use in the class to increase motivation and interest of students is the graphic/visual media, for example is a comic. The purpose of this research is to find out of comic quality. This research approach is research development (R\&D). The developing model in this research and development uses modification of Four-D Model. Based on the above result and discussion it can be concluded: The quality of learning comic review from the validation of the material experts obtained the result of the learning comic having valid criteria with $90.3 \%$. Assessment validation from media expert got result of validation of comic learning have valid criterion with percentage $87,8 \%$. Assessment of validation of linguists on learning comics has valid criteria with $96 \%$ percentage. The results of field trials based on the assessment of teachers and students obtained a percentage of teachers at $87.2 \%$ and at students of $86.5 \%$ (valid).
\end{abstract}

Keywords: Comic, Research and Development, Earth, Universe 


\section{PENDAHULUAN}

Faktor penting yang mempengaruhi kegiatan pembelajaran di kelas adalah media pembelajaran. Penerapan media pembelajaran di kelas dimaksudkan agar proses pembelajaran di kelas menjadi lebih efisien, efektif dan bermakna bagi siswa. Hamalik dalam Arsyad (2006) menyatakan penggunaan media pembelajaran di kelas mampu memberikan rangsangan, membangkitkan motivasi siswa, membangkitkan minat dan mempengaruhi psikologis siswa sehingga suasana belajar menjadi lebih menyenangkan.

Pemanfaatan media pembelajaran di dalam kelas selama proses pembelajaran pada kebanyakan sekolah di Indonesia umumnya kurang inovatif dan cenderung monoton. Monotonnya pengunaan media dalam proses pembelajaran menyebabkan siswa tidak mampu mengikuti pelajaran dengan maksimal sehingga pembelajaran menjadi tidak efektif dan efisien. Observasi awal yang dilakukan di SDN Utama 2 Tarakan dan SDN 17 Tarakan didapatkan hasil pemanfaatan media oleh pengajar masih sebatas penggunaan buku teks dan lembar kerja siswa. Penggunaan media pembelajaran yang monoton dalam pembelajaran berdampak kurangnya motivasi dan minat siswa dalam mengikuti proses pembelajaran. Kurangnya motivasi dan minat juga berpengaruh kepada hasil belajar siswa.

Hasil observasi pada pembelajaran di kelas didapatkan data bahwa siswa banyak mengalami kendala dalam mengikuti pembelajaran yang berisi materi sains. Berdasarkan hasil observasi juga didapatkan persentase gaya belajar siswa pada kelas VI di SDN Utama 2 dan SDN 17 Tarakan sebesar 24,5\% memiliki gaya belajar visual auditori, sebesar 52,5\% memiliki gaya belajar visual kinestetik, sebesar $15 \%$ memiliki gaya belajar visual dan sebesar $8 \%$ memiliki gaya belajar kinestetik.

Salah satu media pembelajaran yang efektif digunakan dalam kelas untuk membangkitkan motivasi dan minat siswa adalah media visual/grafis terutama media komik pembelajaran. Abrori dkk. (2016) menyakatan bahwa media grafik dalam bentuk komik umumnya mampu menarik perhatian, memperjelas sebuah 
sajian materi dan mampu mengilustrasikan suatu fakta atau konsep dengan tampilan menarik dibandingkan dengan penjelasan verbal saja. Waluyanto (2005) juga menyatakan media visual/grafis dalam bentuk komik sangat efisien dalam mengefektifkan pembelajara, karena sebagian besar siswa di tingkat sekolah dasar akan lebih gampang mencerna materi dalam bentuk visual dibandingkan dengan kata (teks) saja.

Media Komik dapat dijadikan alternatif sebagai salah satu media yang efektif dan efisien. Komik dapat menampilkan visualisasi dari materi dengan gambar yang menarik. Karakteristik komik mampu menggabungkan teks dan gambar dalam bentuk yang kreatif. Perpaduan dua unsur ini yang membuat komik mampu dicerna oleh anak di tingkat sekolah dasar. Pratiwi dan Kurniawan (2009) menyatakan unsur visual dalam komik juga mampu lebih dicerna oleh siswa di tingkat sekolah dasar sehingga materi lebih lama diingat.

Salah satu materi di sekolah dasar yang membutuhkan perpaduan visualisasi dan teks adalah materi "Bumi dan Alam Semesta". Materi ini sangat sulit diterapkan berdasarkan konsep kontekstual dan saintifik karena sangat susah dikaitkan dengan kehidupan sehari-hari. Alternatif yang paling logis diterapkan untuk materi ini adalah dengan membuat visualisasi dan teks sehingga materi lebih bisa diterima oleh siswa. Berdasarkan latar belakang di atas diharapkan pengembangan komik pembelajaran mampu mengatasi permasalahan terkait kurangnya media alternatif di dalam kelas pada proses pembelajaran.

\section{METODE PENELITIAN}

Penelitian ini merupakan jenis penelitian pengembangan (research and development). Model pengambangan dalam penelitian dan pengembangan ini menggunakan modifikasi pengembangan perangkat Four-D Model berdasarkan Thiagarajan et al., (1974). Model ini terdiri dari 4 tahap pengembangan yaitu pendefinisian (define), perancangan (design), pengembangan (develop), dan penyebaran (disseminate) atau diadaptasikan menjadi model 4-D (define, design, develop dan disseminate), yaitu pendefinisian, perancangan, pengembangan, dan penyebaran. Pada penelitian dan pengembangan ini, model pengembangan hanya sampai pada langkah develop. 
Tahap pendefinisian (define) adalah tahap untuk menetapkan dan mendefinisikan syarat-syarat pembelajaran. Tahap pendefinisian ini mencakup lima langkah pokok, yaitu: 1) analisis ujung depan (front-end analysis), 2) analisis siswa (learner analysis), 3) analisis tugas (task analysis), 4) analisis konsep (concept analysis) dan 5) perumusan tujuan pembelajaran (specifying instructional objectives).

Tahap perancangan bertujuan untuk merancang perangkat pembelajaran. Empat langkah yang harus dilakukan pada tahap ini, yaitu: 1) penyusunan standar tes (criterion-test construction); 2) pemilihan media (media selection) yang sesuai dengan karakteristik materi dan tujuan pembelajaran; 3) pemilihan format (format selection), yakni mengkaji format-format bahan ajar yang ada dan menetapkan format bahan ajar yang akan dikembangkan; 4) membuat rancangan awal (initial design) sesuai format yang dipilih.

Tahap pengembangan adalah tahap untuk menghasilkan produk pengembangan yang dilakukan melalui dua langkah, yakni: a) penilaian ahli (expert appraisal) yang diikuti dengan revisi; b) uji coba pengembangan (developmental testing). Kriteria kevalidan data angket penilaian validator dapat ditinjau dari hasil presentase kriteria dalam Tabel 1.

Tabel 1 Kriteria Kevalidan Data Angket Penilaian

\begin{tabular}{ll}
\hline \multicolumn{1}{c}{ Skala nilai } & \multicolumn{1}{c}{ Keterangan } \\
\hline $85,94-100 \%$ & Valid (tidak revisi) \\
$67,18-85,93 \%$ & Cukup valid (tidak revisi) \\
$48,44-67,17 \%$ & Kurang valid (revisi) \\
$25-48,43 \%$ & Tidak Valid (revisi) \\
\hline
\end{tabular}

Sumber : diadaptasi dari Suryabrata dalam Ismail. 2007

\section{HASIL DAN PEMBAHASAN}

Berdasarkan hasil dari tahap pendefinisian pada pengembangan komik ini dilakukan observasi di SDN Utama 2 Tarakan dan SDN 17 Tarakan. Hasil dari tahap pendefinisian digambarkan pada Tabel 2.

Tabel 2 Hasil Tahap Pendefinisian

\begin{tabular}{clll}
\hline No & \multicolumn{1}{c}{ Langkah } & \multicolumn{1}{c}{ Deskripsi Hasil } \\
\hline 1 & analisis ujung depan & (front-end \\
& analysis), & $\begin{array}{l}\text { Berdasarkan hasil obeservasi siswa mengalami } \\
\text { kesulitan dalam pemahaman materi terutama } \\
\text { terkait materi sains pada kelas tinggi seperti bumi } \\
\text { dan alam semesta }\end{array}$ \\
\hline 2 & analisis siswa (learner analysis), & Beberapa hal yang diamati pada tahapan ini adalah \\
\hline
\end{tabular}




\begin{tabular}{lll}
\hline No & Langkah & \multicolumn{1}{c}{ Deskripsi Hasil } \\
\hline & gaya belajar siswa. Hasil presentase gaya belajar \\
& siswa didapatkan data sebagai berikut \\
& 1) Visual auditori sebesar 24,5\% \\
& 2) Visual kinestetik sebesar 52,5\% \\
& 3) Visual sebesar 15\% \\
& 4) Kinestetik sebesar 8\% \\
\hline $3 \quad$ analisis tugas (task analysis), & Guru dalam proses pembelajaran umumnya hanya \\
& memberikan tugas dengan lingkup sebatas C1 - \\
& C2, sehingga peneliti merencanakan untuk \\
& meningkatkan tingkatan soal sampai pada C3 untuk \\
& lebih mengasah pemahaman konsep dan aplikasi \\
& konsep oleh siswa \\
\hline $4 \quad$ analisis konsep (concept analysis) & Siswa belum memahami konsep secara maksimal \\
& pada beberapa pelajaran karena umumnya beberapa \\
& materi khususnya materi sains lebih ditekankan \\
& melalui sistem hafalan, berdasarkan beberapa \\
& pertimbangan maka ditetapkan Kompetensi Inti \\
& dan Kompetensi Dasar sebagai berikut
\end{tabular}

1) Kompetensi Int

a) KI 3 : Memahami pengetahuan faktual dan konseptual dengan cara mengamati, menanya dan mencoba berdasarkan rasa ingin tahu tentang dirinya, makhluk ciptaan Tuhan dan kegiatannya, dan benda-benda yang dijumpainya di rumah, di sekolah dan tempat bermain

b) KI 4 : Menyajikan pengetahuan factual dan konseptual dalam bahasa yang jelas, sistematis, logis dan kritis, dalam karya yang estetis, dalam gerakan yang mencerminkan anak sehat, dan dalam tindakan yang mencerminkan perilaku anak beriman dan berakhlak mulia

2) Kompetensi Dasar
a) KD 3.7 : Menjelaskan sistem tata surya dan karakteristik anggota tata surya
b) KD 3.8 : Menjelaskan peristiwa rotasi dan revolusi bumi serta terjadinya gerhana bulan dan gerhana matahari
c) $\mathrm{KD} 4.7:$ Membuat model sistem tata surya
d) KD 4.8 : Membuat model gerhana bulan dan gerhana matahari
5 perumusan tujuan pembelajaran Berdasarkan KI dan KD maka dirumuskan tujuan (specifying instructional objectives). pembelajaran sebagai berikut

1) Siswa mampu menjelaskan urutan sistem tata surya melalui studi literatur dan diskusi dengan tepat

2) Siswa mampu menjelaskan karakteristik tiap planet di tata surya melalui studi literature dan diskusi dengan tepat

3) Siswa mampu menerapkan prinsip rotasi bumi melalui praktikum sederhana dengan tepat

4) Siswa mampu menerapkan prinsip revolusi bumi melalui praktikum sederhana dengan 


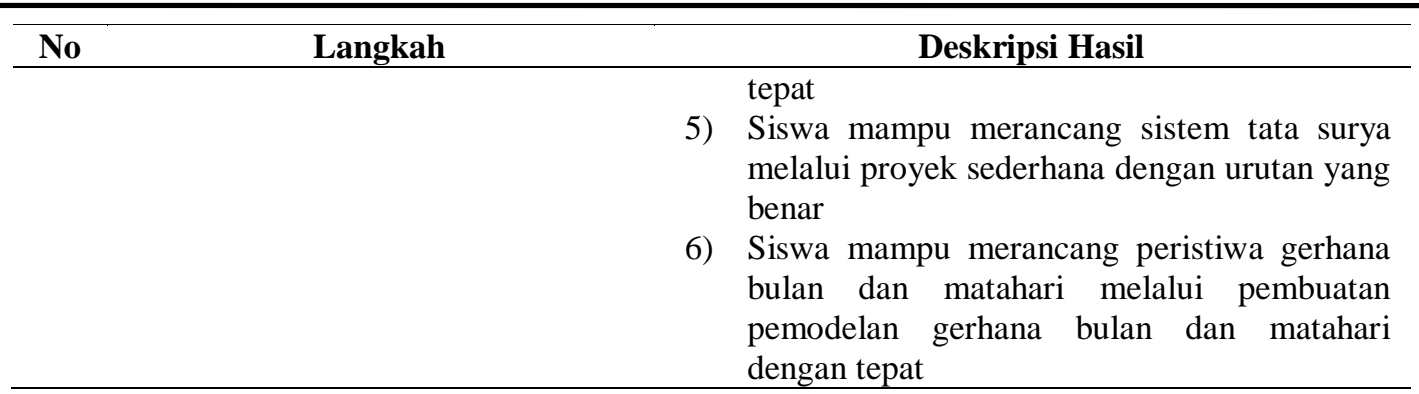

Berdasarkan hasil dari tahap pendefinisian kemudian disusunlah draf media yang akan dikembangkan pada tahap perancangan. Hasil dari tahap perancangan digambarkan pada Tabel 3.

Tabel 3 Hasil Tahap Perancangan

\begin{tabular}{|c|c|c|}
\hline No & Langkah & Deskripsi Hasil \\
\hline 1 & $\begin{array}{l}\text { penyusunan standar tes (criterion- } \\
\text { test construction); }\end{array}$ & $\begin{array}{l}\text { Tugas dalam komik diletakkan pada bagian akhir } \\
\text { komik dengan beberapa rincian tugas, yaitu: } \\
\text { 1) Praktikum dan Diskusi Hasil Praktikum } \\
\text { 2) Studi Kasus terkait Tata Surya } \\
\text { 3) Tes (Soal Pilihan ganda dan Uraian) } \\
\text { Tugas disusun dengan rentang tingkat kesukaran } \\
\text { untuk ranah kognitif antara C1 - C3, sementara } \\
\text { untuk aspek psikomotorik antara P1-P2. }\end{array}$ \\
\hline 2 & pemilihan media (media selection) & $\begin{array}{l}\text { Berdasarkan hasil observasi pada analisis ujung } \\
\text { depan dan analisis siswa, maka dipilih media yang } \\
\text { mewakili gaya belajar visual yaitu media komik } \\
\text { pembelajaran }\end{array}$ \\
\hline 3 & pemilihan format (format selection), & $\begin{array}{l}\text { Format dalam komik mengikuti format standar } \\
\text { komik mengacu kepada Abrori dkk (2016), yang } \\
\text { berisi: } \\
\text { 1) Halaman awal } \\
\text { 2) Prolog dan Pengenalan Tokoh } \\
\text { 3) Inti Cerita } \\
\text { 4) Penutup / Epilog } \\
\text { 5) Penugasan } \\
\text { a) Praktikum dan Diskusi Hasil Praktikum } \\
\text { b) Studi Kasus terkait Tata Surya } \\
\text { c) Tes (Soal Pilihan ganda dan Uraian) } \\
\text { 6) Daftar Pustaka } \\
\text { 7) Glosarium }\end{array}$ \\
\hline 4 & $\begin{array}{l}\text { membuat rancangan awal (initial } \\
\text { design) }\end{array}$ & $\begin{array}{l}\text { Setelah ditentukan format, tes dan konten lain } \\
\text { dalam komik, kemudia komik dirancang dengan } \\
\text { menggunakan beberapa teknik perancangan. } \\
\text { Rancangan komik yang dibuat memiliki } \\
\text { karakteristik sebagai berikut: } \\
\text { 1) Gaya penggambaran komik mengacu kepada } \\
\text { gaya semi-manga dengan gambar berwarna } \\
\text { 2) Genre cerita dibuat genre sains fiksi } \\
\text { 3) Latar komik pada lingkungan sekolah dan } \\
\text { beberapa planet (dalam bagian fiksinya) } \\
\text { 4) Hardware dan software dalam pembuatan } \\
\text { komik menggunakan pen tablet dengan } \\
\text { menggunakan software clip studio dan adobe }\end{array}$ \\
\hline
\end{tabular}




\begin{tabular}{llc}
\hline No & Langkah & Deskripsi Hasil \\
\hline & & photoshop. \\
\hline
\end{tabular}

Penilaian validasi pada penelitian dan pengembangan ini meliputi beberapa angket, yaitu: angket ahli materi, ahli media, ahli bahasa, dan uji coba lapang (praktisi dan siswa).

Penilaian ahli materi meliputi aspek kelayakan isi dan kelayakan penyajian dengan hasil seperti pada Tabel 4.

Tabel 4 Penilaian Ahli Materi pada Komik Pembelajaran

\begin{tabular}{rlc}
\hline No & \multicolumn{1}{c}{ Aspek } & Nilai \\
\hline 1 & Kelayakan isi & 4,53 \\
2 & Kelayakan Penyajian & 4,50 \\
\hline \multicolumn{2}{r}{ Rata-Rata } & 4,51 \\
\hline & Presentase & $90,3 \%$ \\
\hline
\end{tabular}

Penilaian validasi oleh ahli materi merupakan aspek penting dalam penelitian pengembangan. Validasi oleh ahli materi meliputi beberapa kajian isi terkait fakta, ilustrasi, keluasan dan kedalaman materi. Penilaian validasi oleh ahli materi didapatkan kriteria valid (tidak revisi) dengan presentase 90,3\%. Format komik dimulai dengan prolog (pendahuluan), pengenalan tokoh, dan cerita (sekaligus memuat materi) yang digambarkan berdasarkan Gambar 1, Gambar 2 dan Gambar 3.
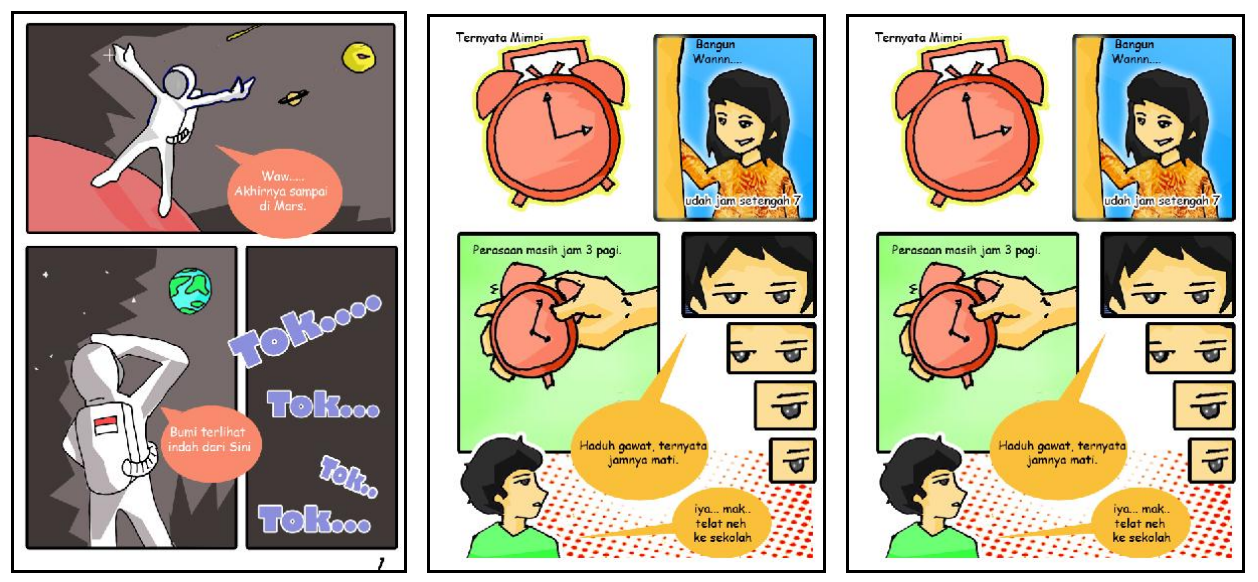

Gambar 1 Prolog sebelum Pengenalan Tokoh dalam Komik

Prolog dalam komik menceritakan si tokoh utama yang bermimpi menjadi astronot. Pada tahap selajutnya si tokoh utama sadar dari mimpinya, karena dibangunkan dari tidur oleh ibunya. Tahap selanjutnya setelah prolog, pengenalan tokoh dalam komik yang digambarkan pada gambar 2 . 


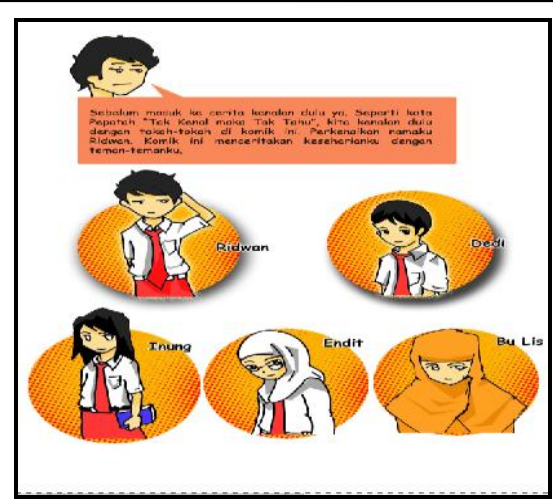

\section{Gambar 2 Pengenalan tokoh dalam komik}

Tokoh dalam komik ini terdiri dari 4 siswa dan 1 guru kelas. Cerita dalam komik ini seputar kehidupan sekolah dari siswa yang mendapatkan sebuah buku ajaib sehingga bisa belajar tentang tata surya dengan bantuan buku ajaib tersebut. Cerita inti dari komik ini sekaligus menceritakan tentang tata surya seperti tergambar digambar 3.
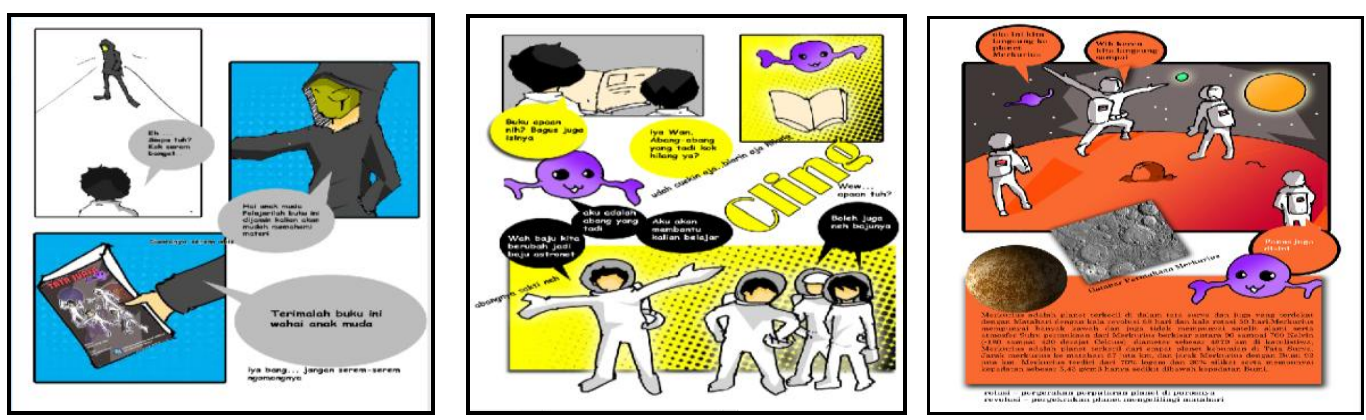

Gambar 3 Inti cerita dan materi

Penilaian ahli media meliputi ukuran buku, desain kulit buku, dan desain isi buku yang digambarkan pada Tabel 3.

Tabel 3 Penilaian Ahli Media pada Komik Pembelajaran

\begin{tabular}{rlc}
\hline No & \multicolumn{1}{c}{ Aspek } & Nilai \\
\hline 1 & Ukuran Buku Ensiklopedia & 4,50 \\
2 & Desain Kulit Buku & 4,33 \\
3 & Desai n isi buku & 4,34 \\
\hline \multicolumn{2}{c}{ Rata-Rata } & 4,39 \\
\hline & Presentase & $87,8 \%$ \\
\hline
\end{tabular}

Validasi oleh ahli media meliputi beberapa aspek terutama terkait ukuran buku, desain sampul, dan desain isi buku. Ukuran buku yang digunakan pada komik ini menggunakan ukuran kertas A5. Penilaian validasi oleh ahli media didapatkan kriteria valid (tidak revisi) dengan presentase 87,8\%. Desain sampul menggunakan background dengan warna gelap disesuaikan dengan warna latar 
ruang angkasa dengan gambar tokoh menggunakan kostum astronot. Sampul untuk komik ini ditunjukkan pada gambar 4.

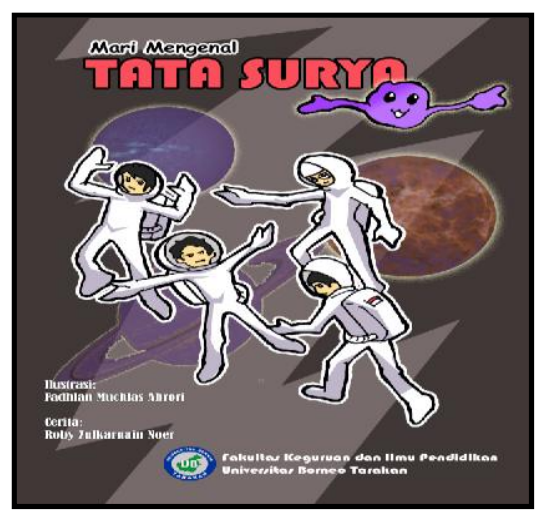

Gambar 4 Sampul untuk Komik

Desain isi buku disesuaikan dengan desain komik pada umumnya dengan menggunakan plot-plot cerita . Plot-plot cerita dilengkapi dengan balon kata sebagai simbol percakapan antar dialog. Desain isi komik seperti tergambar pada gambar 5 .

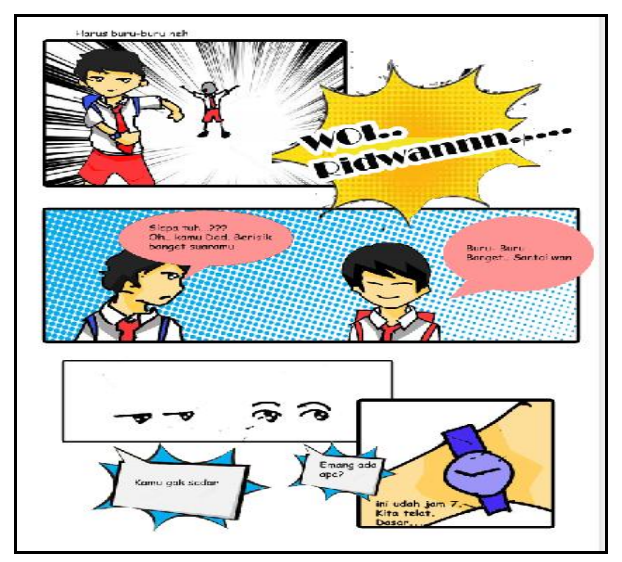

Gambar 5 Desain Isi Komik

Penilaian ahli bahasa meliputi beberapa aspek penilaian meliputi penggunaan bahasa dan ketepatan bahasa.

Tabel 4 Penilaian Ahli Bahasa pada Komik Pembelajaran

\begin{tabular}{rlc}
\hline No & \multicolumn{1}{c}{ Aspek } & Nilai \\
\hline 1 & Penggunaan Bahasa & 4,80 \\
2 & Ketepatan Bahasa & 4,80 \\
\hline \multicolumn{2}{r}{ Rata-Rata } & 4,80 \\
\hline \multicolumn{2}{r}{ Presentase } & $96 \%$ \\
\hline
\end{tabular}

Penilaian validasi ahli bahasa meliputi penggunaan bahasa terkait aspek penilaian meliputi penggunaan bahasa dan ketepatan bahasa. Aspek penggunaan bahasa dan 
ketepatan bahasa dibagi menjadi sub-aspek kejelasan makna kata, ketepatan pemilihan pemilihan kata, kejelasan kalimat, ketepatan istilah dan kemenarikan gaya bahasa. Penilaian validasi ahli bahasa sebesar $96 \%$. Beberapa masukan oleh ahli bahasa terkait beberapa penggunaan istilah yang dianggap sulit untuk diberikan penjelasan terlebih dahulu.

Penilaian guru dan siswa pada komik pembelajaran meliputi: aspek kemudahan, kemenarikan dan keterpahaman.

Tabel 5 Penilaian Guru pada Komik Pembelajaran

\begin{tabular}{rlcc}
\hline No & & Aspek & Nilai \\
\hline 1 & Kemudahan & & 4,33 \\
2 & Kemenarikan & & 4,50 \\
3 & Keterpahaman & & 4,08 \\
\hline & & Rata-Rata & 4,30 \\
\hline & & Presentase & $86 \%$ \\
\hline
\end{tabular}

Tabel 6 Penilaian Siswa pada Komik Pembelajaran

\begin{tabular}{rlcc}
\hline No & & Aspek & Nilai \\
\hline 1 & Kemudahan & & 4,50 \\
2 & Kemenarikan & & 4,65 \\
3 & Keterpahaman & & 4,02 \\
\hline & & Rata-Rata & 4,39 \\
\hline & & Presentase & $87,8 \%$ \\
\hline
\end{tabular}

Penilaian validasi guru dan siswa meliputi 3 aspek, yaitu: kemudahan, kemenarikan dan keterpahaman. Kemudahan meliputi tipografi isi buku, ilustrasi isi, dan daya pemahaman dan tata letak. Kemenarikan meliputi kemenarikan materi. Keterpahaman meliputi keterkaitan antar konsep, penyampaian pesan, keterpaduan antar bab dan keterpaduan antar paragraf. Berdasarkan hasil penilaian guru dan dan siswa didapatkan presentase pada guru sebesar $86 \%$ dan pada siswa sebesar 87,8\% dengan kriteria valid (tidak revisi).

Masukan dari guru dan siswa terkait beberapa kata dalam percakapan masih terlalu sulit untuk dipahami oleh siswa. Beberapa percakapan juga masih menggunakan bahasa yang tidak baku. Masukan lain dari guru dan siswa adalah terkait beberapa background dalam gambar komik yang dianggap terlalu gelap agar dibuat lebih terang, sehingga antara tulisan dan gambar memiliki warna yang tidak saling menutupi satu sama lain. 


\section{KESIMPULAN DAN SARAN}

Berdasarkan hasil dan pembahasan di atas maka dapat disimpulkan: Kualitas komik pembelajaran ditinjau dari penilaian validasi dari ahli materi didapatkan hasil komik pembelajaran memiliki kriteria valid dengan presentase 90,3\%. Penilaian validasi dari ahli media didapatkan hasil validasi komik pembelajaran memiliki kriteria valid dengan presentase $87,8 \%$. Penilaian validasi ahli bahasa pada komik pembelajaran memiliki kriteria valid dengan presentase $96 \%$. Hasil uji coba lapang berdasarkan penilaian guru dan dan siswa didapatkan presentase pada guru sebesar $86 \%$ dan pada siswa sebesar $87.8 \%$ dengan kriteria cukup valid (tidak revisi).

Pengembangan media pembelajaran yang menarik bagi siswa, terutama daerah perbatasan perlu divariasikan sehingga pembelajaran lebih menarik. Variasi media pembelajaran yang menarik perlu peran guru untuk kreatif dan inovatif dalam pembuatan media. Salah satu media yang menarik adalah media grafis terutama komik. Media grafis lain umumnya juga menarik untuk meningkatkan minat dan motivasi siswa. Penelitian selanjutnyya diharapkan dapat dikembangkan lagi media grafis lain yang inovatif dalam mengembangkan minat siswa.

\section{DAFTAR PUSTAKA}

Abrori, F.M., Yulida, R., Adhani, A., Wijarini, F., dan Nugroho, E.D. (2016). Media Pembelajaran Biologi. Yogyakarta : Genom

Arsyad, A. (2006). Media Pembelajaran. Jakarta: PT Raja Grafindo Persada.

Ismail, T. (2007). Pengembangan Modul Ekosistem untuk Pembelajaran Sains di SMP kelas VII dengan Model Siklus Belajar (Learning Cycle) yang Berorientasikan Konstruktivisme. Skripsi tidak diterbitkan. Malang: Universitas Negeri Malang.

Pratiwi, W., dan Kurniawan, R.Y. (2012). Penerapan Media Komik sebagai Media Pemebelajaran Ekonomi di SMA Negeri 3 Ponorogo. Artikel Publikasi. UNESA. Surabaya

Thiagarajan, S., Semmel, D. S \& Semmel, M. I. (1974). Instructional Development for Training Teachers of Expectional Children. Minneapolis, Minnesota: Leadership Training Institute/Special Education, University of Minnesota.

Waluyanto, H. D.,(2005). Komik sebagai Media Komunikasi Visual Pembelajaran. Jurnal Nirmana 7 (1): 45-50. 